\title{
Pengaruh Penambahan Inhibitor Alami terhadap Laju Korosi pada Material Pipa dalam Larutan Air Laut Buatan
}

\author{
Ardi Prasetia Yanuar ${ }^{1}$, Herman Pratikno ${ }^{1}$, dan Harmin Sulistiyaning Titah $^{2}$ \\ ${ }^{1}$ Jurusan Teknik Kelautan, Fakultas Teknologi Kelautan, Institut Teknologi Sepuluh Nopember (ITS) \\ ${ }^{2}$ Jurusan Teknik Lingkungan, Fakultas Teknik Sipil dan Perencanaan, Institut Teknologi Sepuluh Nopember (ITS) \\ J1. Arief Rahman Hakim, Surabaya 60111 Indonesia \\ e-mail: hermanp@oe.its.ac.id
}

\begin{abstract}
Abstrak- Korosi merupakan penurunan mutu logam akibat adanya reaksi elektrokimia dengan lingkungannya. Banyak faktor yang dapat menyebabkan korosi suatu material, salah satu diantaranya yakni pengaruh konsentrasi media korosi. Ada banyak metode untuk menghambat proses terjadinya korosi. Salah satu diantara banyak metode yaitu penggunaan inhibitor. Inhibitor organik salah satu jenis inhibitor yang bersifat nontoksik, murah, sudah tersedia di alam, mudah diperbaharui dan tidak merusak lingkungan. Inhibitor organik tersebut diperoleh dengan mengekstrak beberapa bahan yang ada di alam. Dalam penetilitian ini inhibitor yang digunakan antara lain daun jambu biji, daun teh, kedelai dan kopi. Inhibitor tersebut digunakan pada material pipa baja dalam media air laut buatan yang memiliki kadar salinitas 35 \%. Metode perhitungan laju korosi baja menggunakan metode weight loss dan electroplating. Laju korosi paling kecil yakni sebesar 3.10 mpy untuk API 5L dan 1.94 mpy untuk ASTM A53 dengan inhibitor daun teh. Inhibitor yang kurang maksimal dalam menghambat laju korosi yaitu inhibitor kopi yakni 6.12 mpy untuk API 5L dan 2.66 mpy untuk ASTM A53. Nilai laju korosi spesimen API 5L dan ASTM A53 yang tidak menggunakan inhibitor masing-masing 50.26 mpy dan 3.83 mpy. Inhibitor teh memiliki nilai effisiensi mencapai 93.83\%. Sedangkan daun jambu biji memiliki nilai effisiensi mencapai $93.45 \%$. Nilai effisiensi inhibitor kedelai mencapai $\mathbf{9 1 . 7 2 \%}$ dan inhibitor kopi memiliki nilai effisiensi paling rendah hanya mencapai $87.83 \%$.
\end{abstract}

Kata Kunci- Daun Jambu Biji, Daun Teh, Electroplating, Inhibitor, Kedelai, Kopi, Korosi, Weight Loss

\section{PENDAHULUAN}

$\mathrm{K}$ OROSI merupakan penurunan mutu logam akibat adanya reaksi elektrokimia dengan lingkungannya. Logam yang mengalami penurunan mutu tidak hanya melibatkan reaksi kimia namun juga reaksi elektrokimia, yakni antara bahanbahan yang bersangkutan dengan terjadinya perpindahan electron [1]. salah satu proses perusakan material khususnya logam karena adanya suatu reaksi antara logam tersebut dengan lingkungan. Proses perusakan material yang terjadi menyebabkan turunnya kualitas material logam tersebut [2]. Banyak faktor yang dapat menyebabkan korosi suatu material, salah satu diantaranya yakni pengaruh konsentrasi media korosi. Pada media air laut, ion-ion klorida menjadi salah satu sumber masalah terhadap material yang mengalami korosi. Semakin banyak konsentrasi ion-ion klorida maka dapat mempercepat proses korosi yang terjadi di lingkungan laut [3].
Salah satu metode penghambat proses terjadinya korosi yaitu dengan menggunakan inhibitor korosi. Inhibitor korosi adalah suatu zat kimia yang bila ditambahkan ke dalam suatu lingkungan, dapat menurunkan laju korosi yang terjadi pada lingkungan tersebut terhadap suatu logam didalamnya. Menurut bahan dasar pembuatannya inhibitor korosi dapat dibedakan menjadi dua jenis yaitu inhibitor yang terbuat dari bahan anorganik dan organik. Inhibitor korosi organik yaitu inhibitor korosi yang berasal dari bahan alami yang tersedia di alam. inhibitor organik selain dapat menghambat laju korosi. Inhibitor alami memiliki sifat non-toksik, murah, mudah didapatkan dan dapat diperbaharui [4].

Saat ini bidang inhibitor korosi sedang mengalami perubahan drastis dari sudut pandang kompatibilitas lingkungan. Lembaga lingkungan di berbagai negara telah memberlakukan aturan ketat dan peraturan untuk penggunaan dan pembuangan inhibitor korosi. Peraturan lingkungan yang ketat mengharuskan inhibitor korosi untuk menjadi ramah lingkungan dan aman [5].

Daun jambu biji memiliki kandungan senyawa tanin yang dapat digunakan untuk menghambat proses korosi yang terjadi. Kandungan tanin yang dimiliki daun jambu biji cukup tinggi. Di dalam daun teh juga terkandung senyawa tanin dan kafein. Tanin dan kafein yang ada di dalam daun teh dapat pula digunakan sebagai penghambat laju korosi. Pada biji kopi terkandung senyawa kafein yang dapat digunakan sebagai penghambat laju korosi. Asam amino di dalam biji kedelai juga dapat digunakan sebagai senyawa untuk menghambat laju korosi yang terjadi pada material.

Saat ini sudah mulai berkembang penelitian mengenai inhibitor korosi alami dan penggunaannya. Penggunaan tumbuhan tembakau, teh dan kopi sebagai inhibitor korosi baja lunak [6]. Penggunaan ekstrak daun pepaya sebagai inhibitor korosi pada baja AISI 4140 dalam medium air laut [7]. Ekstrak teh, kopi, dan tembakau yang digunakan sebagai inhibitor korosi pada cat utuk pelat kapal A36 [8].

Berdasarkan hal tersebut, penulis ingin melakukan percobaan dengan melakukan penambahan ekstrak daun jambu biji, kacang kedelai, daun teh, dan kopi sebagai bahan inhibitor organik pada material pipa. Media yang digunakan sebagai media korosi yaitu air laut. Media korosi air laut tersebut penulis menggunakan kadar salinitasnya 35\%. 
Metode pengambilan data laju korosi dengan menggunakan metode immersion test dan metode electroplating.

\section{DASAR TEORI}

\section{A. Korosi}

Korosi adalah salah satu proses perusakan material khususnya logam karena adanya suatu reaksi antara logam tersebut dengan lingkungan. Proses perusakan material yang terjadi menyebabkan turunnya kualitas material logam tersebut [2]. Korosi yang terjadi pada benda logam merupakan sebuah hal yang akan selalu terjadi dan tidak dapat dihindarkan. Korosi merupakan proses yang terjadi secara alami dan tidak akan biasa berhenti selama logam tersebut masih berada di lingkungan yang bersifat korosif. Proses ini akan merusak logam dengan cara mengikis logam yang kemudian akan menurunkan sifat-sifat mekanis yang dimiliki oleh logam tersebut. Pada umumnya reaksi korosi yang terjadi merupakan reaksi elektrokimia [9].

Terdapat beberapa faktor yang mempengaruhi laju korosi dalam sistem elektrolit larutan (aqueous) diantaranya adalah:

\section{1) Komponen ion larutan dan konstentrasinya}

Konsentrasi larutan menyatakan jumlah zat terlarut dalam setiap satuan larutan atau pelarut. Dalam sebuah larutan dengan konsentrasi tertentu, zat penyusun larutan tersebut akan terurai menjadi ion-ion (baik berupa kation maupun anion) pembentuknya [10].

\section{2) Kadar Oksigen}

Oksigen terlarut akan meningkatkan reaksi katoda sehingga logam akan semakin teroksidasi (terkorosi) [10].

3) Kecepatan (pergerakan fluida)

Kecepatan aliran fluida yang tinggi di atas kecepatan kritisnya di dalam pipa berpotensi menimbulkan korosi. Dengan rusaknya permukaan logam, rusak pula lapisan film pelindung sehingga memudahkan terjadinya korosi.

\section{B. Inhibitor Korosi}

Inhibitor korosi merupakan suatu zat kimia yang bila ditambahkan ke dalam suatu lingkungan, dapat menurunkan laju korosi yang terjadi pada lingkungan tersebut terhadap suatu logam didalamnya. Pada prakteknya, jumlah yang di tambahkan adalah sedikit, baik secara kontinu maupun periodik menurut suatu selang waktu tertentu [9]. Inhibitor korosi menurut bahan pembuatannya dibagi menjadi dua yaitu inhibitor dengan bahan baku alami dan inhibitor buatan. Inhibitor alami yaitu inhibitor yang terbuat dari bahan organik yang dapat diperbarui seperti contohnya tanaman dan buahbuahan. Secara keseluruhan senyawa inhibitor adalah netral tetapi, gugus nitrogen pada senyawa memiliki pasangan elektron bebas yang menyebabkan inhibitor cenderung bermuatan negatif sehingga, inhibitor akan tertarik ke permukaan logam dan membentuk lapisan [11].

\section{Daun Teh}

Daun teh mememiliki beberapa kandungan penting yang sangat berguna bagi manusia. Beberapa kandung yang dimaksud antara lain kafein, theofilin, tanin, adenine, minyak atsiri, kuersetin, naringenin, dan natural fluoride. Daun teh mengandung sekitar $2-4 \%$ senyawa kafein. Sedangkan di dalam daun teh terdapat kandungan zat tanin sekitar 8-18\% didalamnya [12].

\section{Daun Jambu Biji}

Tanaman jambu biji (Psidium guajava) merupakan tanaman yang berasal dari Amerika, banyak ditanam sebagai tanaman buah-buahan yang tumbuh pada ketinggian 1-1.2 m diatas permukaan laut dan merupakan tanaman perdu atau pohon kecil, tinggi tanaman umumnya 3-10 m [13]. Kandungan kimia yang terdapat dalam jambu biji yaitu buah, daun, dan kulit batang pohon jambu biji mengandung tanin. Sedangkan pada bunganya tidak banyak mengandung tanin. Daun Jambu biji juga mengandung zat lain seperti minyak atsiri, asam ursolat, asam psidiolat, asam kratogolat, asam oleanolat, asam guajaverin, dan vitamin. Daun jambu biji yang digiling halus diketahui mempunyai kandungan tanin sampai $17 \%$ [14]

\section{E. Kedelai}

Kedelai (Glycine max (L.) Merril) merupakan tanaman pangan turunan kedelai jenis liar Glycine Ururiencis berbentuk semak yang tumbuh tegak. Kandungan nutrisi yang terdapat dalam kedelai adalah energi, karbohidrat, gula, serat, lemak, protein, asam amino, dll. Kandungan asam aminio dalam kacang kedelai cukup tinggi yaitu sekitr $42 \%$ dari total berat keringnya.

\section{F. Kopi}

Tanaman kopi (Coffea sp.) termasuk familia Rubiaceae dan merupakan tanaman tropis yang banyak diperdagangkan di dunia. Tanaman kopi memiliki kandungan senyawa kafein yang dapat digunakan sebagai bahan untuk pembuatan inhibitor korosi dari bahan alami.

\section{G. Tanin}

Tanin merupakan senyawa organik yang sangat kompleks dan banyak terdapat pada bermacam-macam tumbuhan. Tanin merupakan suatu senyawa kompleks dalam bentuk campuran polifenol yang sukar dipidahkan [14]. Tanin kaya akan senyawa polifenol yang mampu menghambat proses oksidasi sehingga laju korosi dapat menurun.

\section{H. Kafein}

Inhibitor kafein merupakan inhibitor organik sehingga, proses penginhibisiannya disebabkan adsorbsi molekul dalam permukaan logam. Inhibitor teradsorbsi pada permukaan logam membentuk lapisan pasif yang melindungi logam terhadap korosi lebih lanjut. Kafein merupakan alkaloid yang mempunyai cincin purin dan merupakan derivate dari metil xanthine (1,3,7-trimetil xanthine) dengan BM 194,14, specific gravity 1,23 [15].

\section{Asam amino}

Asam amino adalah sembarang senyawa organik yang memiliki gugus fungsional karboksil $(-\mathrm{COOH})$ dan amina (biasanya -NH2). Dalam biokimia seringkali pengertiannya dipersempit: keduanya terikat pada satu atom karbon (C) yang sama (disebut atom C "alfa" atau $\alpha$ ). Gugus karboksil memberikan sifat asam dan gugus amina memberikan sifat basa. Dalam bentuk larutan, asam amino bersifat amfoterik, cenderung menjadi asam pada larutan basa dan menjadi basa pada larutan asam [16]. 


\section{METODE PENELITIAN}

\section{A. Pembuatan Spesimen}

Material pipa dipotong dan dibentuk menjadi plat. Setelah material pipa menjadi bentuk plat, maka dibuat spesimen dengan ukuran $20 \mathrm{~mm}$ x $20 \mathrm{~mm}$ x $3 \mathrm{~mm}$. Spesimen berbentuk plat kecil yang kemudian dilakukan proses penghalusan permukaan material dengan menggunakan kertas amplas. Lalu, spesimen yang telah dihaluskan permukaannya direndam dengan larutan HCL yang disebut dengan proses pickling. Proses pickling ini bertujuan untuk menghilangkan kerak pada permukaan, lapisan korosi, maupun pengotor lain yang menempel pada permukaan spesimen. Kemudian, spesimen dibersihkan dengan air mengalir dan sabun agar material bersih dan siap digunakan.

\section{B. Pembuatan Larutan}

Pembuatan larutan rendam yaitu dengan mencampurkan padatan $\mathrm{NaCl}$ ke dalam larutan aquades dengan jumlah tertentu. Lalu aduk larutan tersebut hingga bercampur rata.

\section{Pembuatan Inhibitor}

Bahan pembuat inhibitor yaitu kedelai, daun jambu, kopi, dan daun teh dihaluskan terlebih dahulu. Kemudian ditimbang sebanyak 200 gram dan mempersiapkan pelarut N-Heksan sebanyak $650 \mathrm{ml}$. Pembuatan inhibitor menggunakan metode pendingin tegak atau refluks. Masukkan bahan inhibitor dan pelarut ke dalam tabung elenmeyer dan pasang alat ekstraksi pendingin tegak. Kemudian panaskan diatas hot plate selama kurang lebih 1 jam hingga warna N-Heksan berubah karena tercampurnya senyawa bahan inhibitor dengan pelarut. Saring larutan campuran dengan kertas saring agar dapat dipisahkan antara padatan dan larutan yang akan digunakan pada proses selanjutnya. Dinginkan larutan campuran tersebut dengan cara diangin-anginkan. Setelah itu, panaskan kembali pada wadah terbuka agar pelarut N-Heksan dapat menguap. Pada proses ini perlu diperhatikan temperatur maksimum yang dimiliki oleh pelarut. Setelah larutan tersebut mengental, maka dinginkan dengan cara didiamkan selama beberapa waktu dan inhibitor siap digunakan.

\section{Pengujian Immersion Test}

Pengujian immersion test dilakukan dengan cara merendam spesimen yang sudah dibuat ke dalam larutan rendam air laut buatan. Pengujian dilakukan selama 14 hari. Lalu setelah dilakukan pengujian rendam maka dilakukan perhitungan laju korosi yang terjadi. Spesimen yang digunakan sebelumnya dilapisi dengan inhibitor yang telah dibuat dan ada satu spesimen yang tidak menggunakan lapisan inhibitor guna pembanding hasil nantinya.

\section{E. Pengujian Electroplating}

Pengujian korosi menggunakan metode electroplating yaitu dengan merendam spesimen dan elektroda ke dalam larutan air laut buatan. Dalam proses perendaman tersebut, dialirkan air listrik untuk membantuk proses pengujian. Waktu pengujian tiap spesimen yaitu 30 menit dan 60 menit. Setelah dilakukan pengujian, spesimen dibersihkan lalu dikeringkan.
Setelah itu dapat dilakukan penimbangan berat akhir guna mengetahui perubahan berat yang terjadi.

\section{F. Uji Fotomikro}

Spesimen yang telah dilakukan pengujian dilanjutkan dengan proses foto mikrostruktur. Spesimen dihaluskan permukaannya terlebih dahulu dengan mesin polisher. Kertas amplas yang digunakan untuk mesin polisher yakni dari no.80 hingga no.2000. Lalu, spesimen yang telah dihaluskan permukaannya, dibersihakan permukaannya dengan larutan campuran alcohol dan HNO3. Hal ini bertujuan agar struktur mikro pada material dapat terlihat pada mikroskop. Kemudian dilakukan proses foto mikro menggunakan mikroskop.

\section{HASIL DAN DISKUSI}

\section{A. Hasil Ekstraksi Inhibitor}

\section{1) Daun Teh}

Hasil ekstrak daun teh kering yang dijadikan inhibitor berupa pasta berminyak berwarna hijau kehitaman. Aroma teh yang ada pada hasil inhibitor dangat kuat. Ketika diaplikasikan pada permukaan material spesimen, warna yang melekat pada permukaan tersebut yaitu hijau kehitaman.

\section{2) Kopi}

Inhibitor kopi yang merupakan hasil ekstraksi bubuk kopi menunjukkan warna coklat kehitaman yang lebih jernih dibanding dengan kopi bubuk pada umumnya. Aroma kopi masih tercium kuat pada inhibitor yang dihasilkan.

\section{3) Kacang Kedelai}

Inhibitor kacang kedelai berwarna orange kental dengan aroma kedelai yang cukup kuat. Warna yang dihasilkan tidak sama dengan warna kacang kedelai saat berwujud biji yang berwarna kuning.

\section{4) Daun Jambu}

Inhibitor daun jambu berwarna hitam kecoklatan yang cukup pekat dan aroma yang dihasilkan kurang sedap. Wujud inhibitor lebih kental dan lebih pekat dibanding inhibitor kopi dan inhibitor kacang kedelai.

\section{B. Pengujian Dengan Metode Immersion Test}

Data yang digunakan dalam perhitungan laju korosi didapatkan dari pengujian korosi dengan metode immersion test. Laju korosi paling besar terjadi pada spesimen tanpa menggunakan inhibitor yakni sebesar 50.26 mpy untuk material API 5L dan 3.83 mpy untuk material ASTM A53. Laju korosi yang dimiliki cukup tinggi karena kedua spesimen tersebut tidak dilapisi oleh inhibitor apapun. Sedangkan untuk spesimen yang dilapisi oleh inhibitor, laju korosi paling besar yakni pada material yang dilapisi oleh inhibitor kopi. Laju korosi inhibitor kopi sebesar 6.12 mpy untuk material API 5L dan 2.66 mpy untuk material ASTM A53. Spesimen dengan lapisan inhibitor kopi memiliki nilai laju korosi yang tinggi karena inhibitor kopi tidak langsung melekat pada permukaan spesimen sehingga inhibitor kopi mudah bercampur dengan larutan air laut buatan yang digunakan dalam pengujian.

Pada spesimen yang dilapisi oleh inhibitor teh memiliki laju korosi paling kecil yaitu sebesar 3.10 mpy untuk material API 
5L dan 1.94 mpy untuk material ASTM A53. Inhibitor teh mampu menghambat laju korosi lebih baik daripada inhibitor yang lain karena inhibitor teh memiliki daya rekat pada permukaan material yang lebih baik. Sehingga dapat melapisi material dan memperlambat permukaan material bereaksi langsung dengan larutan rendam.

\section{Laju Korosi Material Pipa dengan metode immersion test}

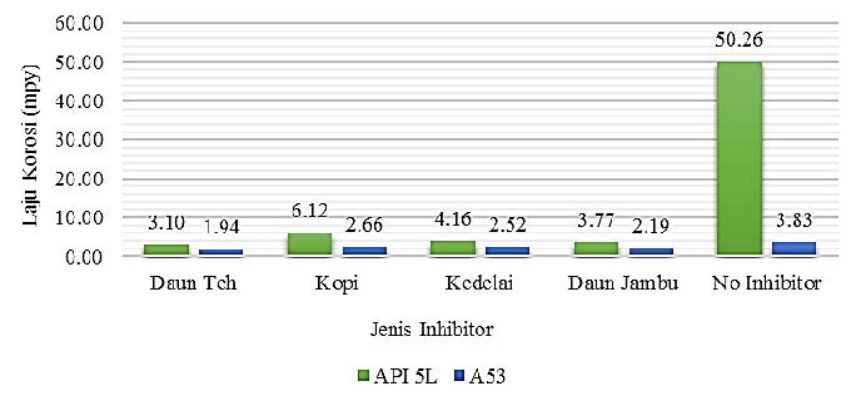

Gambar 1. Grafik perbandingan laju korosi material pipa dengan menggunakan metode immersion test

\section{Effisiensi Inhibitor dengan metode immersion test}

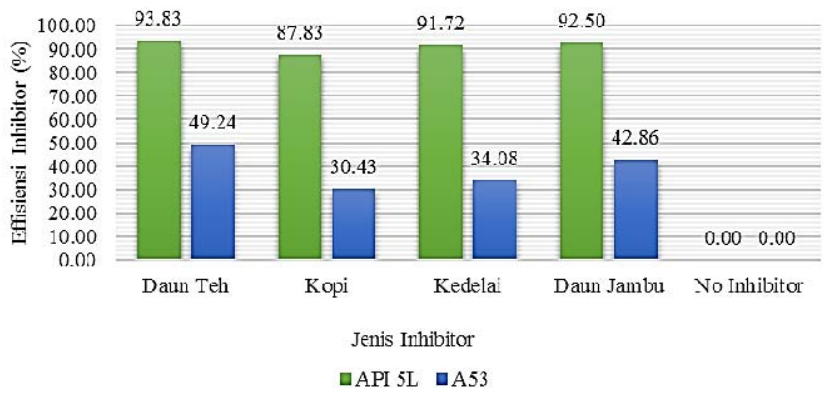

Gambar 2. Grafik perbandingan effisiensi inhibitor yang dimiliki tiap jenis inhibitor yang dipakai dengan metode immersion test.

Jenis inhibitor yang memiliki nilai effisiensi inhibitor paling besar yaitu inhibitor teh. Nilai effisiensi inhibitor teh pada material API 5L dan ASTM A53 masing-masing 93.83\% dan $49.42 \%$. Sedangkan nilai effisensi inhibitor paling kecil yaitu inhibitor kopi yang hanya memiliki $87.83 \%$ untuk material API 5L dan $30.43 \%$ untuk material ASTM A53. Selisih nilai effisiensi yang dimiliki inhibitor teh dan inhibitor kopi mencapai $18.81 \%$. Nilai inhibitor daun jambu mencapai $92.50 \%$ sedikit dibawah nilai effisiensi yang dimiliki oleh inhibitor teh dan nilai effisiensi inhibitor kedelai mencapai $87.83 \%$.

Dari nilai effisiensi inhibitor yang dimiliki oleh inhibitor daun teh dan Daun Jambu maka dapat dikatakan bahwa kedua inhibitor ini merupakan inhibitor yang baik untuk proses menghambat korosi. Material yang tidak menggunakan inhibitor memiliki tingkat korosi yang paling tinggi karena tidak ada yang melindungi permukaan material spesimen tersebut.

\section{Pengujian Dengan Metode Electroplating}

Laju korosi paling besar terjadi pada spesimen tanpa menggunakan inhibitor yakni sebesar 8552.45 mpy untuk material API 5L dan 30257.08 mpy untuk material ASTM A53. Laju korosi yang dimiliki cukup tinggi karena kedua spesimen tersebut tidak dilapisi oleh inhibitor apapun. Sedangkan spesimen yang dilapisi oleh inhibitor, laju korosi paling besar yakni pada material yang dilapisi oleh inhibitor kopi.

\section{Laju Korosi Material Pipa dengan metode electroplating}

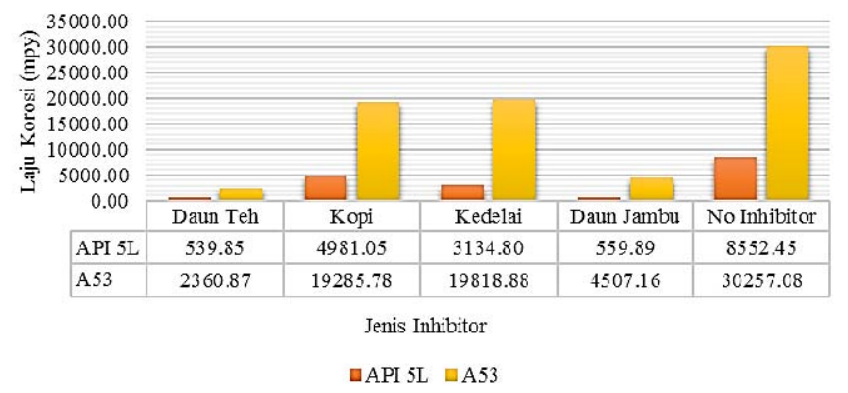

Gambar 3. Grafik perbandingan laju korosi material pipa dengan menggunakan metode electroplating.

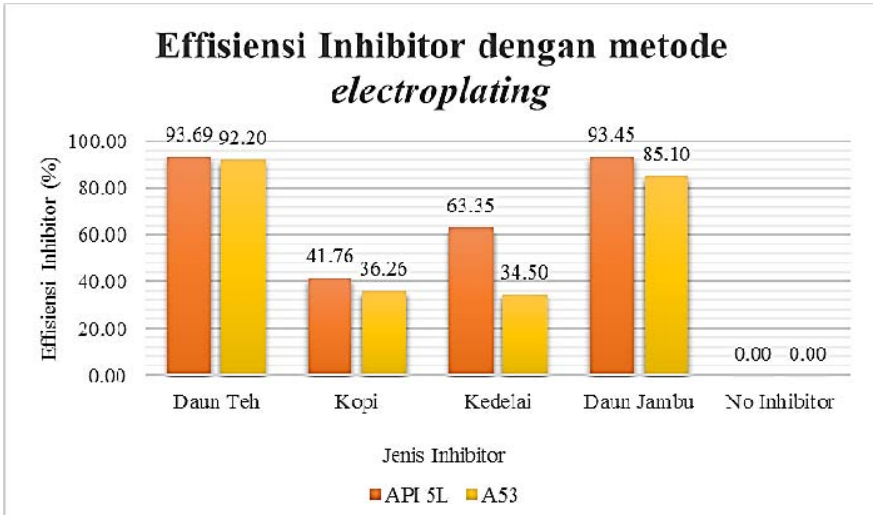

Gambar 4. Grafik perbandingan effisiensi inhibitor yang dimiliki tiap jenis inhibitor yang dipakai dengan metode electroplating.

Laju korosi inhibitor kopi sebesar 4981.05 mpy untuk material API 5L dan 19285.78 mpy untuk material ASTM A53. Spesimen dengan lapisan inhibitor kopi memiliki nilai laju korosi yang tinggi karena inhibitor kopi tidak langsung melekat pada permukaan spesimen sehingga inhibitor kopi mudah bercampur dengan larutan air laut buatan yang digunakan dalam pengujian.

Pada spesimen yang dilapisi oleh inhibitor teh memiliki laju korosi paling kecil yaitu sebesar 539.85 mpy untuk material API 5L dan 2360.87 mpy untuk material ASTM A53. Inhibitor teh mampu menghambat laju korosi lebih baik daripada inhibitor yang lain karena inhibitor teh memiliki daya rekat pada permukaan material yang lebih baik. Sehingga dapat melapisi material dan memperlambat permukaan material bereaksi langsung dengan larutan rendam. 
Jenis inhibitor yang memiliki nilai effisiensi inhibitor paling besar yaitu inhibitor teh. Nilai effisiensi inhibitor teh pada material API 5L dan ASTM A53 masing-masing 93.69\% dan $92.20 \%$. Sedangkan nilai effisensi inhibitor paling kecil yaitu inhibitor kopi yang hanya memiliki $41.76 \%$ untuk material API 5L dan 36.26\% untuk material ASTM A53. Selisih nilai effisiensi yang dimiliki inhibitor teh dan inhibitor kopi mencapai $63.34 \%$. Nilai inhibitor daun jambu mencapai $93.45 \%$ sedikit dibawah nilai effisiensi yang dimiliki oleh inhibitor teh dan nilai effisiensi inhibitor kedelai mencapai $63.35 \%$.

\section{Hasil Uji Foto Mikrostruktur}

Setelah dilakukan pengujian korosi dengan menggunakan metode immersion test dan electroplating maka dilakukan uji foto mikrostruktur guna mengetahui bentuk struktur material. 1) ASTM A53

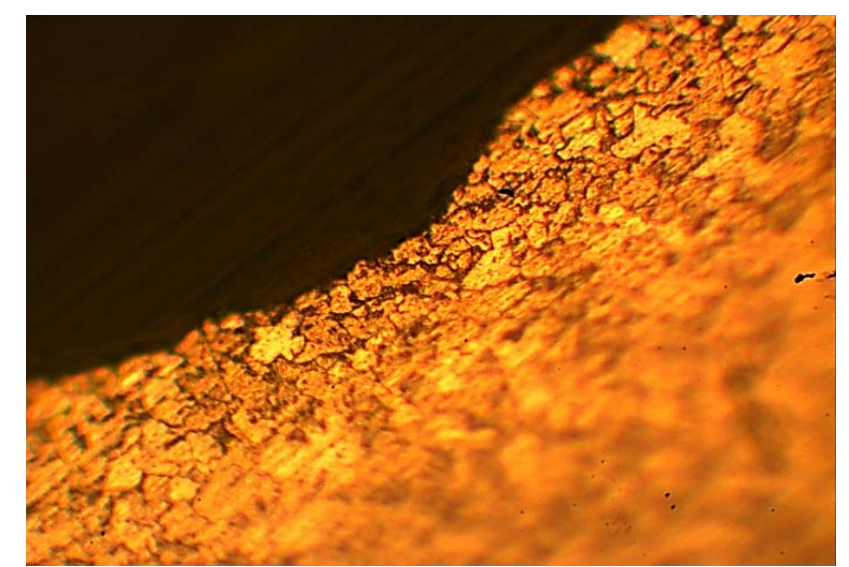

Gambar 5. Permukaan spesimen material A53 400x tidak mengalami korosi

Struktur mikro pada gambar di atas terdiri dari butir-butir ferit yang berwarna terang, dan butir-butir perlit berwarna gelap. Butir ferit cenderung lebih halus sedangkan butir perlit lebih kasar.

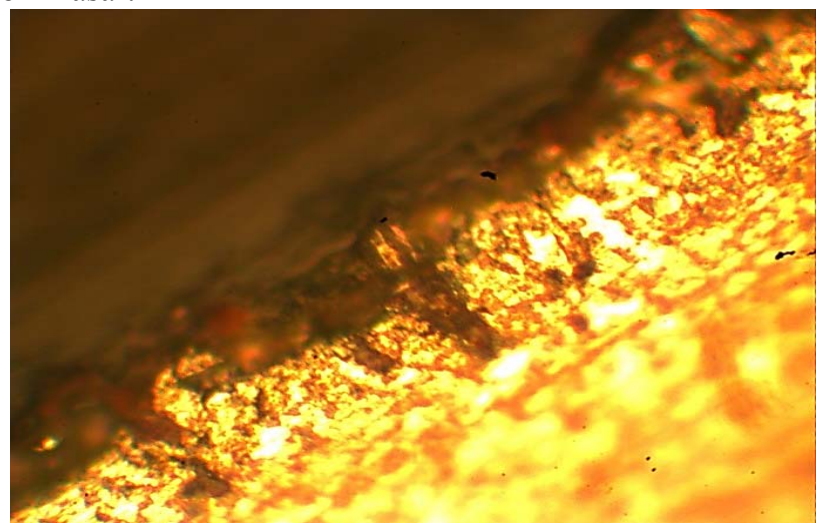

Gambar 6. Permukaan spesimen material A53 400x yang mengalami proses korosi

\section{2) $A P I 5 L$}

Setelah material API 5L digunakan untuk melakukan proses uji korosi, maka dapat dilakukan uji foto mikrostruktur pada permukaan spesimen. Pada gambar 7 merupakan penampakan struktur mikro material dengan perbesaran 400x. Gambar

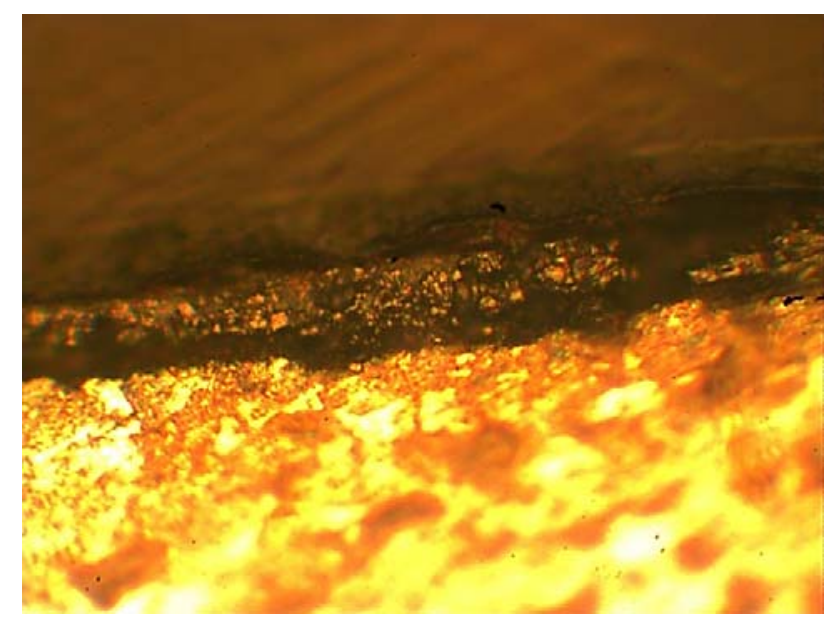

Gambar 7. Permukaan spesimen material API 5L 400x tidak mengalami korosi

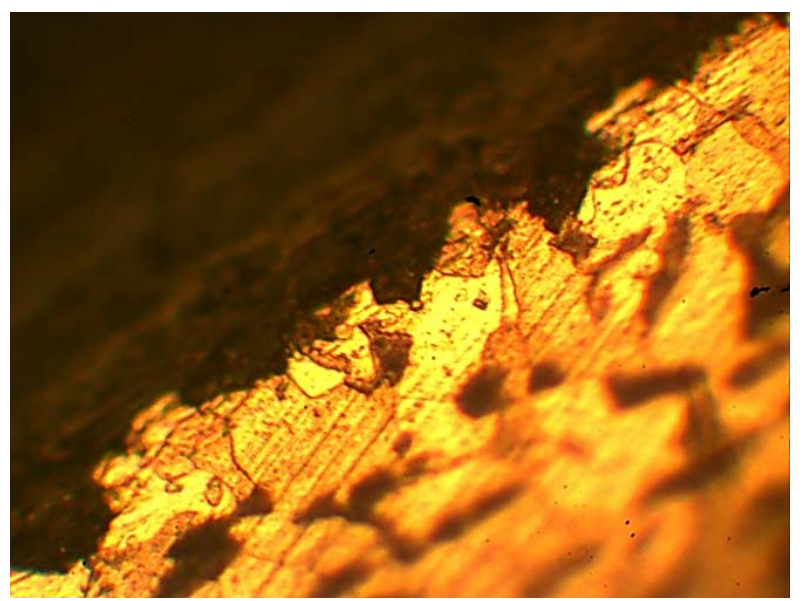

Gambar 8. Permukaan spesimen material API 5L 400x mengalami korosi

tersebut merupakan penambakan struktur material sebelum mengalami proses korosi.

Namun, pada gambar 8 pada bagian tepi spesimen terlihat celah yang merupakan hasil dari proses korosi yang terjadi pada permukaan material tersebut.

Bagian tepi material menjadi tidak rata seperti sebelumnya. Struktur mikro pada gambar di bawah terdiri dari butir-butir ferit yang berwarna terang, dan butir-butir perlit berwarna gelap.

\section{KESIMPULAN}

1. Laju korosi spesimen dengan inhibitor teh memiliki laju korosi paling kecil yakni sebesar 3.10 mpy untuk API 5L dan 1.94 mpy untuk ASTM A53. Spesimen dengan inhibitor daun jambu memiliki laju korosi yang lebih besar dari spesimen dengan inhibitor teh yakni sebesar 3.77 mpy untuk API 5L dan 2.19 untuk ASTM A53. Nilai laju korosi pada material dengan inhibitor kopi yakni 6.12 mpy untuk API 5L dan 2.66 mpy untuk ASTM A53. Spesimen dengan inhibitor kacang kedelai memiliki nilai laju korosi sebesar 
4.16 untuk API 5L dan 2.52 mpy untuk ASTM A53. Nilai laju korosi spesimen API 5L dan ASTM A53 yang tidak menggunakan inhibitor masing-masing 50.26 mpy dan 3.83 mpy. Kandungan tanin pada daun teh dan daun jambu biji, kafeina pada kopi, dan asam amino pada kacang kedelai dapat menghambat proses korosi. Senyawa tersebut akan membentuk lapisan pelindung pada permukaan material. Sehingga, inhibitor alami yang digunakan mampu menghambat laju korosi pada material spesimen API 5L dan ASTM A53. Material yang dilapisi inhibitor memiliki nilai laju korosi yang lebih rendah dibandingkan dengan spesimen yang tidak dilapisi oleh inhibitor.

2. Inhibitor teh merupakan inhibitor dengan kinerja yang paling baik dengan nilai effisiensi mencapai $95.48 \%$. Sedangkan daun jambu biji memiliki nilai effisiensi mencapai $93.45 \%$. Inhibitor tersebut memiliki daya rekat yang lebih kuat dibanding dengan yang lain. Sedangkan, inhibitor kacang kedelai memiliki kinerja yang kurang maksimal. Nilai effisiensi inhibitor kedelai mencapai 91.72\% sedikit dibawah nilai effisiensi inhibitor teh dan kopi. Lapisan pelindung yang dibuat oleh inhibitor kacang kedelai lebih cepat hilang dan daya rekat yang dimiliki juga kurang kuat. Inhibitor kopi memiliki nilai effisiensi paling rendah dan hanya mencapai $87.83 \%$. Hal ini terjadi karena lapisan yang dibentuk inhibitor sangat mudah terlepas dari permukaan spesimen. Kinerja inhibitor dapat dipengaruhi oleh daya rekat inhibitor pada permukaan material. Semakin pekat inhibitor yang dihasilkan maka semakin baik daya rekat terhadap material. Semakin kuat daya rekat yang dimiliki inhibitor terhadap material, maka semakin kuat lapisan yang dibentuk oleh inhibitor tersebut untuk menghambat laju korosi yang terjadi.

\section{UCAPAN TERIMA KASIH}

Penulis mengucapkan terima kasih kepada teknisi Laboratorium Kimia Organik D3 Teknik Kimia ITS, teknisi Laboratorium Sanitasi Lingkungan dan Fitoteknologi Teknik Lingkungan ITS, dan teknisi Laboratorium Kontruksi dan Kekuatan Teknik Perkapalan ITS yang telah memberikan ijin, bantuan, dan arahan dalam melakukan percobaan tugas akhir ini. Penulis juga mengucapkan terima kasih kepada semua pihak yang sudah membantu penulis dalam menyelesaikan tugas akhir ini baik secara langsung maupun tidak langsung.

\section{DAFTAR PUSTAKA}

[1] Tretheway, Kr., Chamberlain J. 1991. Korosi untuk Mahasiswa dan Rekayasawan. Jakarta: PT. Gramedia Pustaka Utama.

[2] Pattireuw, Kevin Jones, Fentje Abdul Rauf, dan Romels Cresano. 2013. Analisis Laju Korosi pada Baja Karbon dengan Menggunakan Air Laut dan $\mathrm{H}_{2} \mathrm{SO}_{4}$. Teknik Mesin. Manado: Universitas Sam Ratulangi.

[3] Yuliarti, Iftitahul F. 2016. Pengaruh Penambahan Tapioka pada Inhibitor Ekstrak Daun Jambu Biji (Psidium guajava l.) terhadap Efisiensi Inhibisi Korosi Baja Api $5 L$ grade B pada Lingkungan Ph 4 dan $\mathrm{Ph}$ 7. Tugas Akhir. Surabaya: Jurusan Teknik Material dan Metalurgi, Fakultas Teknik Industri Institut Teknologi Sepuluh Nopember.

[4] Karim, Azis Abd. Dan Zulkifly A. Yusuf. 2012. "Analisa Pengaruh Penambahan Inhibitor Kalsium Karbonat dan Tapioka Terhadap Tingkat Laju Korosi pada Pelat Baja Tangki Ballast Air Laut”. Jurnal Riset dan Teknologi Kelautan (JRTK) 10 (7): 205-212.
[5] Sastri, V.S. 2011. Green Corrosion Inhibitors: Theory and Practice. Hoboken: John Wiley \& Sons, Inc.

[6] Ilim, Kamisah D Pandiangan dan Sudrajat. 2007. "Studi Penggunaan Tumbuhan Tembakau, Teh dan Kopi sebagai Inhibitor Korosi Baja Lunak dalam Air Laut Buatan yang Jenuh $\mathrm{CO}_{2}$ ". Jurnal Sains MIPA 13 No.2 (12): 163-168.

[7] Irianty, Rozanna Sri dan Khairat. 2013. Ekstrak Daun Pepaya (Carica papaya) sebagai Inhibitor Korosi Baja ST.37 dalam Medium Asam Sulfat. Jurnal Teknobiologi IV (2): 77-82.

[8] Septiari, Roni dan Heri Supomo. 2013. Studi Penggunaan Ekstrak Bahan Alami Sebagai Inhibitor Korosi Pada Cat Utuk Pelat Kapal A36. Jurnal Teknik POMITS (2): 1-5

[9] Gumelar, Agung Akhmad. 2011. Studi Pengaruh Konsentrasi Ekstrak Teh Roselia (Hibbicus sabdariffa) sebagai Green Corrosion Inhibitor untuk Material Baja Karbon Rendah di Lingkungan $\mathrm{NaCl}$ 3,5\% pada Temperatur 50 Derajat Celsius. Skripsi. Depok: Teknik Material dan Metalurgi, Fakultas Teknik Universitas Indonesia.

[10] Hakim, Alfin Al. 2011. Pengaruh Inhibitor Korosi Berbasiskan Sunyawa Fenolik untuk Proteksi Pipa Baja Karbon pada Lingkungan 0.5, 1.5, 2.5, 3.5\% NaCl yang Mengandung Gas $\mathrm{CO}_{2}$. Skripsi. Depok: Teknik Material dan Metalurgi, Fakultas Teknik Universitas Indonesia.

[11] Kristian, Andy dan Setyo Purwanto. 2015. Pengaruh Inhibitor Kafeina terhadap Laju Korosi Baja API 5L Grade B dalam Media Air Laut. Tangerang: BATAN PUSPITEK

[12] Habibie, Afithroni Lubis dan Aisyah Endah Palupi. 2014. "Pengaruh Daun Teh dan Daun Jambu Biji sebagai Inhibitor Organik Alami pada Baja SS 304 dalam Larutan Asam”. Jurnal Teknik Mesin (JTM) 03 No.01: 9-13.

[13] Akhsan, M.Luki Yudha. 2015. Pengaruh Inhibitor Ekstrak Daun Jambu Biji Merah Terhadap Laju Korosi Baja A131 Pada Air Laut. Skripsi. Jember: Teknik Mesin, Fakultas Teknik Universitas Jember.

[14] Fachry, A Rasyid, RM.Arief Sastrawan, dan Guntur Svingkoe. 2012. Kondisi Optimal Proses Ekstraksi Tanin dari Daun Jambu Biji Menggunakan Pelarut Etanol. Prosiding STNK TOPI (7): 69-73.

[15] Haryono, Gogot, Bambang Sugiarto, Hanima Farid dan Yudi Tanoto. 2010. Ekstrak Bahan Alam sebagai Inhibitor Korosi. Prosiding Seminar Nasional Teknik Kimia "Kejuangan" (1): 1-6.

[16] Rafiqi, Ach. Firdaus dan Achmad Junaidi. 2012. Asam Amino: Gerak dan Perubahan. Materi Ajar. Sumenep: Universitas Wiraraja. 